DOI: https://doi.org/10.34069/AI/2022.49.01.3

How to Cite:

Sagan O.V., Blakh V.S., Los O.N., Liba O.M., \& Kazannikova O.V. (2022). The use of augmented reality technology in primary education. Amazonia Investiga, 11(49), 27-35. https://doi.org/10.34069/AI/2022.49.01.3

\title{
The use of augmented reality technology in primary education
}

\section{Використання технології доповненої реальності у початковій освіті}

Received: November 2, 2021

\begin{abstract}
In the article it had been analyzed a supplemented reality as a technology of the digital didactics, isolated the applications AR of the educated orientation, which can be useful in primary school. With an aim of checking the positive impact of the applications of a supplemented reality of the educated orientation on the development of the cognitive activity and the improvement of studying results of pupils it had been organized the pedagogical experiment. Diagnostics was used on the different levels of the forming the educated and cognitive interest, the cognitive activity, the educated motivation and success. The received results supported the hypothesis of the investigation, and its summing up let us make the conclusions about that the immersive technologies in the educated process which have become the didactic means, which need the active application.
\end{abstract}

Keywords: digital didactics, technology of the supplemented reality, cognitive activity, applications.

\section{Introduction}

The fluent digitalization of all aspects of human being, including also the education, helps to the
Accepted: December 18, 2021

Written by:

Sagan O.V. ${ }^{6}$

https://orcid.org/0000-0002-3195-3686

Blakh V.S. 7

https://orcid.org/0000-0001-6349-1183

Los O.N.8

https://orcid.org/0000-0002-0177-9381

Liba O.M. ${ }^{9}$

https://orcid.org/0000-0001-6278-913X

Kazannikova O.V. ${ }^{10}$

https://orcid.org/0000-0002-7207-3749

\section{Анотація}

У статті проаналізовано доповнену реальність як технологію цифрової дидактики, виокремлено застосунки AR освітнього спрямування, які можна використовувати у початковій школі. 3 метою перевірки позитивного впливу застосунків доповненої реальності освітнього спрямування на розвиток пізнавальної активності i покращення навчальних досягнень учнів був організований педагогічний експеримент. Діагностиці підлягали рівні сформованості навчальнопізнавального інтересу, пізнавальної активності, навчальної мотивації та успішності. Отримані результати підтвердили гіпотезу дослідження, a їx узагальнення дозволило зробити висновки про те, що іммерсивні технології в освітньому процесі стають дидактичним засобом, потребуючим активного впровадження.

Ключові слова: цифрова дидактика, технологія доповненої реальності, пізнавальна активність, застосунки AR.

process of a modernization of its components and the methodical systems. So, the interactive tech-

\footnotetext{
${ }^{6}$ Docent, $\mathrm{PhD}$, Kherson State University, Ukraine.

${ }^{7}$ Docent, PhD, Kherson State University, Ukraine.

${ }^{8}$ Docent, $\mathrm{PhD}$, Kherson State University, Ukraine.

${ }^{9}$ Docent, PhD, Mukachevo State University, Ukraine.

${ }^{10}$ Docent, $\mathrm{PhD}$, Kherson State University, Ukraine.
} 
nologies let make active the interaction of all subjects of the educative process, enriching its possibil-ities of the gamification, bright threedimensional objects, and so on. Immersive technologies, in par-ticular the virtual (VR) and supplemented (AR) reality, open perfectly the new possibilities for the recognition the new things, and so attract attention of the specialists, working in the education field. In many investigations it has been substantiated an expediency of the introduction of the defined appli-cations as means of the visualization of the studying material, in particular, in the textbooks and manuals (Cieutatet al., 2012; Rizov and Rizova, 2015; Sagan and Lazaruk, 2020; Tran, Nguyen, Do \& Nguyen, 2020; Putra et al., 2021).

As well as if the usage of the technology of the virtual reality is enough expensive and demands the supplemented material resources, so the supplemented reality stops to become the technology of the future, fluently enlarging the quality of the own users and authors.

Such expansion of the greater extent had begun with the drawings, which «revive» and acquired the popularity by help of the commercial projects (cards on yogurts, the bonus cards or books with the illustrations AR and so on). Actually, threedimension animation can transform the reading and the educational process in the playful one, using all the sensor systems in maximum. Together with it, in the real school practice the technologies of the supplemented reality can be used very seldom. To our point of view, the reasons of it is a small quality of the definite publications and methodical works, a lack of information of the teachers as to the mobile applications AR of the educated orientation, ab-sence of the experience of its usage.

The aim of the investigation is an experimental checking up of the effect of an usage of the mobile applications of the supplemented reality as means of the raising of the cognitive activity, the improving of results of the cognitive activity of primary school pupils and the working out of definite methodical recommendations.

\section{Theoretical Framework}

The successfulness of the educated activity of the primary school pupil depends on many factors, among which the priority place takes place his desire to learn, that is a motivation to this kind of the activity. From the psychological point of view, a motivation - it's a system of all the kinds of motives of the personality (demands, motives, interests, aims, installations, ideals), which regulate the behavior and the human activity (Prikhodko and Yurchenko, 2020).

A motivation to the studying is immediately connected with the cognitive interest. The availability of the cognitive interest stimulates the cognitive activity of the young pupil. It needs to suggest that the cognitive activity in the majority of cases is forming spontaneously. The absence or the deficient cognitive ability often is a reason of the worsening the results of studying, so it's important that a teacher can purposefully formulate the cognitive activity, stimulate the cognitive interest, making an influence in a such way on the effectiveness of the studying activity.

It became obvious, so called, the deformations in the development of the personality, caused by the active life in the digital world: the informative acceleration, the clip thinking, the constant sensor hunger, the misbalance in the types of the perception and thinking, the loss of the world boundaries and so on.

The situation, caused by the applications of the pandemia COVID-19, had strengthened these negative tendencies and pushed the educated people to the research and introduction of new forms of the or-ganization of educated process, in particular the distant and blended. In the heart of the last - is a conception of the uniting the traditional and electronic studying which based on the wide usage of the $\mathrm{f}$ digital technologies (Rizky et al., 2021; Bicen \& Bal, 2016).

In the conditions of studying not only the accents are changing between the didactic categories (content, methods, means, studying forms), but also is appeared the necessity of their radical upgrade (Sagan et al., 2020). It happens the transformation of the classical theory studying in the digital didactics due to the demands and needs of the digital society and digital economics, the peculiarities of modern «dig-ital» generation, pedagogical possibilities of modern means of studying. Today in the world are widen the tendencies of usage such technologies of digital didactics, as an adaptative learning; large data; neurotechnologies and artificial intellect; robototechnics; virtual and supplemented realties; Inter-net-objects and so on.

In our study, we turned to immersive technologies. Virtual Reality (VR) is a technology that allows the user to fully plunge into the artificial world with the help of appropriate hardware and software. VR provides immersive real-time simulations entirely using digital graphics. This makes the technology quite 


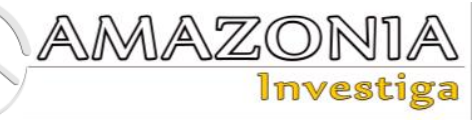

expensive, which slows down its widespread use for educational purposes.

Augmented Reality (AR) is a technology that combines digital information with information from the physical world, allowing users to simultaneously interact with virtual objects and view the physical environment (usually through a digital camera on a mobile phone or tablet) (Fernandez, 2017). Ronald T. Azuma, as the author of many studies in the field of augmented reality, notes that AR combining the virtual and the real, exists in real time, has the effect of visualization in 3D (Azuma, 1997).

Real world and virtual information are synchronized thanks to geolocation and built-in sensors that determine the location of the user in relation to his environment and adapt the display to his move-ments.Numerous studies have found a positive impact of virtual reality on the learning process. Im-proving $\mathrm{AR}$ and $\mathrm{VR}$ through a variety of technological advances allows for a new type of learning that better meets the needs of the 21st century student who wants entertainment, interactivity, participation, and object manipulation. This has been the subject of many studies (Bacca et al., 2014; Hruntova et al., 2018; Ivanov, et al., 2018; Arici et al., 2019; Bondarenko et al., 2020).

There are studies that show the following positive benefits: learning becomes more enjoyable and effective, even when it comes to research and knowledge of abstract concepts or complex phenomena, reduces cognitive load, increases motivation and interest in the course, expands interaction between students, new opportunities for individual training, increasing success (Fernandez, 2017).

In the case study "learning by design" the use of AR has shown an increase in students' level of independent thinking, creativity and critical analysis (Bower et al., 2014). AR technologies create unique technological, managerial and cognitive challenges for teaching and learning (Dunleavy et al., 2009).

In its majority the definite investigations direct to the teenagers and students. A dependence of the motivation, cognitive activity and the studying results of primary school pupils on the usage of the digital didactics usage is little-studied.

Han et al., (2015) investigated the effect of an augmented reality system on enhancing children's sat-isfaction and sensory participation in dramatic play activities. The results of this work showed an in-crease in children's interest in dramatic play, independent involvement and interaction.

Hidayat et al., (2021) analyze the positive impact of augmented reality on learning outcomes and mo-tivation in elementary school students to learn. Their research proves that augmented reality technol-ogy allows for the direct creation of student learning experiences.

\section{Materials and Methods}

Hypothesis. In the educated process the usage of the technologies in the process of technologies of the supplemented reality influences the intensification of the cognitive activity, studying motivation and success of primary school pupils on the level of statistically important differences.

For the empirical investigation we used the following complex of the diagnostic methods:

1. Methods of a defining of the levels of the formation of studying and cognitive interest (Repkina and Zaiika, 1993).

This method presupposes the evaluation and the analysis of children's reaction on the new material, their studying interest on the basis of the observation for the activity during the lessons. A quality evaluation of the results of the defining the studying and cognitive interest makes it by the awarding points (1-4), depending on the level of the forming of the studying and cognitive interest.

1) point: low level, which witnesses about the absence of the studying and cognitive interest;

2) points: middle level, witnesses about the availability of the positive reactions on the new material, which concerns the concrete facts;

3) points: middle level, witnesses about the express of curiosity to new theoretical material;

4) points: high level, witnesses about the situation studying interest.

2. Test questionnaire for the studying of cognitive activity of pupils (Pashnev, 2007).

Method lets to define the different levels of the cognitive activity of a child, comparing it with the normative figures in accordance with the age category. Questionnaire consists of 42 questions oriented on the studying of the cognitive activity. 
Diagnostics of school motivation (Terletska, 2013).

3. Test - questionnaire devotes to the differentiate the motivation of young pupil to the studying at school.

4. Evaluation of success of the young pupils in studying has been made by the way of accounting of middle arithmetical index of success of every pupil for the previous year of studying.It needs to mention that in conditions of the conducted empirical research we had chosen the points and its diagnostics didn't demand the long-term procedures.

\section{Design of investigations}

In the empiric investigations take place 43 young pupils in the age of 9 till 10 years, among those 26 girls and 17 boys. Experimental group $(p=18)$, control $(\mathrm{p}=25)$. The investigation had been made by the steps during 2020 year.

The aim of stated diagnostics was in the defining of level of formation and peculiarities of the cognitive activity, interest, motivation and success in the studying of the children of young school age.

The quantity analysis of the received results showed that in the control and in the experimental classes the normal indexes of the cognitive interest, cognitive activity, studying interest and the level of success are in the boundaries of the middle level (experimental: 2.7, 21, 18.6, 9.2; control: 2.5, 20.6, 16.4, 9.0).

For the comparison of the results of the stated investigation it had been made the frequency analysis of the empiric data by all the indexes in the experimental and control classes (table 1, table 2).

Table 1.

Distribution of the indexes of the expressiveness of cognitive interest, studying motivation, levels of successfulness of the young pupils by the levels in the experimental class $(p=18)$

\begin{tabular}{|c|c|c|c|c|c|c|}
\hline \multirow{3}{*}{ Indexes } & \multicolumn{6}{|c|}{ Levels } \\
\hline & \multicolumn{2}{|c|}{ High } & \multicolumn{2}{|c|}{ Middle } & \multicolumn{2}{|c|}{ Low } \\
\hline & $\mathrm{N}$ & $\%$ & $\mathrm{~N}$ & $\%$ & $\mathrm{~N}$ & $\%$ \\
\hline Cognitive interest & 6 & 33.3 & 10 & 55.5 & 2 & 11.2 \\
\hline Cognitive activity & 4 & 22.2 & 11 & 61.2 & 3 & 16.6 \\
\hline Studying motivation & 6 & 33.3 & 9 & 50 & 3 & 16.6 \\
\hline Level of success & 3 & 16.6 & 15 & 83.4 & 0 & 0 \\
\hline
\end{tabular}

Table 2.

Distribution of the indexes of the expressiveness of cognitive interest, studying motivation, levels of a success of the young pupils by levels in a control class $(p=25)$

\begin{tabular}{|c|c|c|c|c|c|c|}
\hline \multirow{3}{*}{ Indexes } & \multicolumn{6}{|c|}{ Levels } \\
\hline & \multicolumn{2}{|c|}{ High } & \multicolumn{2}{|c|}{ Middle } & \multicolumn{2}{|c|}{ Low } \\
\hline & $\mathrm{N}$ & $\%$ & $\mathrm{~N}$ & $\%$ & $\mathrm{~N}$ & $\%$ \\
\hline Cognitive interest & 7 & 28 & 15 & 60 & 3 & 12 \\
\hline Cognitive activity & 5 & 20 & 16 & 64 & 4 & 16 \\
\hline Studying motivation & 10 & 40 & 11 & 44 & 4 & 16 \\
\hline Level of success & 4 & 16 & 21 & 84 & 0 & 0 \\
\hline
\end{tabular}

The given data witness about the perfect cognitive of pupils, the presence of the cognitive interest and the forming attitude the ir to themselves as to the pupil. The predominance of the middle level of the expressiveness of the cognitive activity witnesses about the interest of the researched pupils at the beginning of work, about the ability to join in the making the tasks without delay, however, as showed the investigation, in the majority of the respondents the interest to the studying tasks rather quickly go out. Such pupils put comparably not so many questions, the own initiative in the making of tasks do not bring in. The pupils with a high cognitive activity keep the cognitive activity during the long term, make efforts for the overcoming the difficulties which appear in the work, bring in the activity the elements of the initiative, fantasy. The most alarm call the pupils with the low level of the cognitive activity. Such 


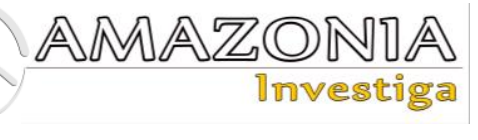

pupils join to the work after the supplemented motives, they often delay. The interest of a child to the task is situational.

Table 3.

The coefficients of the correlation indexes of the cognitive interest, studying motivation, the success of studying activity of the young schoolchildren.

\begin{tabular}{lllll}
\hline & $\begin{array}{l}\text { Cognitive } \\
\text { interest }\end{array}$ & $\begin{array}{l}\text { Cognitive } \\
\text { activity }\end{array}$ & $\begin{array}{l}\text { Study } \\
\text { motivation }\end{array}$ & $\begin{array}{l}\text { Study } \\
\text { success }\end{array}$ \\
\hline Cognitive interest & $*$ & +0.86 & +0.76 & +0.7 \\
Cognitive activity & +0.86 & $*$ & +0.72 & +0.57 \\
Study motivation & +0.76 & +0.72 & $*$ & +0.7 \\
Study success & +0.7 & +0.57 & +0.7 & $*$ \\
\hline
\end{tabular}

The correlation analysis showed the presence of the strong positive connection between the cognitive activity and cognitive interest $(+0.86)$ and between the cognitive interest and studying motivation (+0.76). Between the indexes of the cognitive activity and studying success also it had been appeared a positive connection $(+0.7)$. A similar connection there is between the cognitive motivation and the cognitive success $(+0.7)$. As well it had been defined the positive connection between the cognitive interest and the studying success (+0.57). All the calculated coefficients of the correlation are on the definite level of the amount (0.05).

Thus, having been done stated diagnostics showed that there is an interconnection between the cognitive interest and the cognitive activity, studying motivation and cognitive interest. The essential connection appears between the indexes of the cognitive activity and the studying success and between the cognitive interest and the studying success.

With the aim of checking up of the investigation hypothesis we organized the whole number of activities in the experimental class. So, during the first semester 2020 year we endeavor did not break the logic of classes, add to its content usage of the technology AR. The supplemented reality (or AR) - this is a technology that join the digital information with the information from the environment of the physical world. It let to users at the same time to interact with the virtual objects and look through the physical environment (as usual through the digital camera on the mobile telephone or clipboard) (Billinghurst, 2002). It holds the synchronization of a real world and the virtual information because of the geolocation and in-built transducers which define the place of the spreading of the user in accordance with its environment and adapt the display of its motions. The applications that use AR, can be as simple so complicated. For example, the elementary are as quick text messages or also in this rate to be important as an agenda of doing the surgeon operation of the extraordinary complication. They can enlarge the understanding of different things, extract the definite moments or give the accessible and instant data.

The work is imposed to us which had been done by the investigators M. Anderson (2017), having made the interactive board of applications with a technology use AR (Fig. 1).

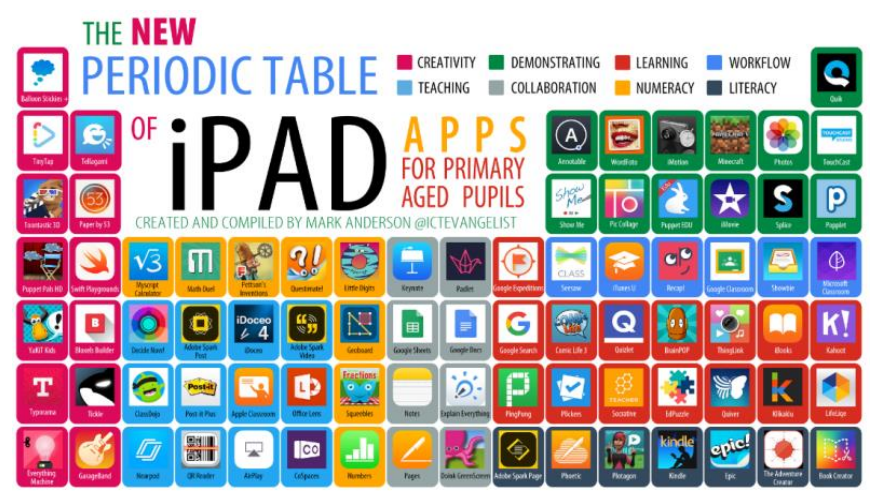

Figure 1. Interactive board AR of applications. 
The authors of this table did not only systematize by the categories (art and design, geography, literature, science, creativeness, history, mathematics, study), but also used the effect of the interactivity which is in that during the touching the icon (label of application), appears the short description of its functioning.

Since the subject of our investigation is connected with the educated activity, in particular in primary school, we defined the applications, which can be used for our age category.
The analysis of the proposed applications let make the conclusions about the possibilities of the usage of technology of the supplemented reality in education, letting that it helps visually recreate the processes which the material objects do not recreate, make the educated process more visible and interesting, increase the thirst to knowledge. The scope for the usage is wide from the adding of the animation in textbooks and manuals for the visualization of the material to the three-dimensional studying presentations which let visually show that or another process (Fig. 2).

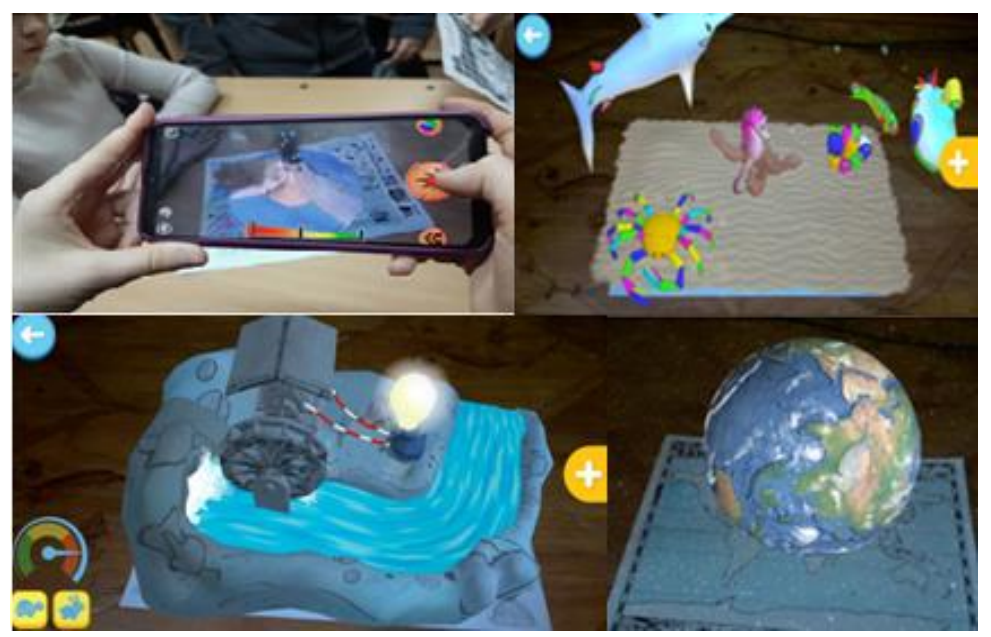

Figure 2. Examples of the usage AR-applications in a work.

\section{Results and Discussion}

The effectiveness and the results of a pupil's work mostly depend on that how attractive the built process of the transferring of knowledge and what it means is defined the direction on the deepening of knowledge further.

For the comparison of the results of control investigation was done the frequency analysis of empiric data by all the indexes (table 4, table 5).

Table 4.

Distribution of the indexes of the expressiveness of cognitive interest, studying motivation, levels of successfulness of the young pupils by the levels in the experimental class $(p=18)$

\begin{tabular}{lllllll}
\hline & \multicolumn{3}{l}{ Levels } & \multicolumn{3}{l}{} \\
\cline { 2 - 7 } Indexes & High & & Middle & Low \\
& $\mathrm{N}$ & $\%$ & $\mathrm{~N}$ & $\%$ & $\mathrm{~N}$ & $\%$ \\
Cognitive interest & 6 & 33.3 & 10 & 55.5 & 2 & 11.2 \\
Cognitive activity & 4 & 22.2 & 11 & 61.2 & 3 & 16.6 \\
Studying motivation & 6 & 33.3 & 9 & 50 & 3 & 16.6 \\
Level of success & 3 & 16.6 & 15 & 83.4 & 0 & 0 \\
\hline
\end{tabular}


Table 5.

Distribution of the indexes of the expressiveness of cognitive interest, studying motivation, levels of a success of the young pupils by levels in a control class ( $p=25)$

\begin{tabular}{lllllll}
\hline \multirow{2}{*}{ Indexes } & \multicolumn{2}{l}{ Levels } & \multicolumn{3}{l}{ Middle } & Low \\
\cline { 2 - 7 } & High & & N & $\%$ & N & $\%$ \\
Cognitive interest & $\mathrm{N}$ & $\%$ & 18 & 72 & 3 & 12 \\
Cognitive activity & 4 & 16 & 17 & 68 & 4 & 16 \\
Studying motivation & 4 & 16 & 19 & 76 & 2 & 8 \\
Level of success & 4 & 16 & 21 & 84 & 0 & 0 \\
\hline
\end{tabular}

The results of the control experiment witnessed in the experimental class the raising of the indexes of the high level of the formation: cognitive interest - on $11.2 \%$; cognitive activity on $17.3 \%$; study motivation - on $16.7 \%$; study success - on $5.6 \%$ against the little improve of such indexes in the control class.

The received results let us make the conclusion about the supporting of the investigation hypothesis in accordance to which the usage in the educated process of technologies of the supplemented reality influences the activation of the cognitive activity, study motivation and success and the pupils' success of primary school.

Our results confirm the results of previous studies. The use of augmented reality technologies is based on $3 \mathrm{D}$ objects and thus provides a new way to get more accurate information about the topic being studied. There is a direct interaction between the object and the subject of learning, so that students can construct and develop their own knowledge. The results also confirmed that students can simultane-ously apply and synthesize several cognitive skills and work together. Moreover, in our study, we proposed a toolkit for measuring the quality of knowledge and motivation of students. This is in line with the request for the need to search for appropriate methods in the work of Bacca et al., (2014)

However, we confirm the findings of Hidayat et al., (2021) that the use of augmented reality technology for primary school students can have both positive and negative impacts. This is due to the lack of study time allotted for the study of the topic, excessive excitement of children, technical difficulties, lack of evidence-based approaches to the use of AR in elementary school.

\section{Conclusions}

The received data showed that the usage in the educated process of technologies of the supplemented reality helped the activation of the cognitive activity and the raising level of study success of primary school pupils and the generalizing of the results of the having done investigation let make some conclusions and recommendations:

The technology of the supplemented reality only start to use in the educated process of primary school and make a challenge of some difficulties of the technical and pedagogical character. So, except the weak erudition as to the possibilities of the additions AR and the insufficient level of the forming of the digital skills of the teachers, actualized the problems of the organizational and methodical character, for example, the absence of the distinct planning, on which step of the lesson is necessary to use AR.

The necessity of taking into consideration the level of the digital competence of each pupil, his perfect technical training for the usage by gadget and application. It gives the definite boundaries or makes actual the distribution of the roles of pupils in the group: someone makes a draft, someone fixes the results, someone demonstrates «come to life» with the smartphone in hands, someone answers and so on.

The organization of the preparing work which presupposes the consequence of the question with the parents as to the usage by the children of their smartphones in the concrete lessons.

So, the having done investigation states that the technologies of the supplemented reality in the educated process become the didactic means, which need the scientific background and the active application.

\section{Conflict of interests}

The authors declare no conflict of interest. 


\section{Bibliographic References}

Anderson, M. (2017). The New Periodic Table Of IPad Apps For Primary Aged Pupils. Ictevangelist. Retrieved from https://ictevangelist.com/the-new-periodictable-of-ipad-apps-for-primary-aged-pupils/

Arici, F., Yildirim, P., Caliklar, Ş., Yilmaz, R.M. (2019). Research trends in the use of augmented reality in science education: Content and bibliometric mapping analysis. Computers \& Education, 142. doi: 10.1016/j.compedu.2019.103647

Azuma, R.T. (1997). A Survey of Augmented Reality. Presence: Teleoperators and Virtual Environments, 6(4), 355-385. Retrieved from

https://www.cs.unc.edu/ azuma/ARpresence .pdf

Bacca, J., Baldiris, S., Fabregat, R., Graf, S., \& Kinshuk. (2014). International Forum of Educational Technology \& Society Augmented Reality Trends in Education: A Systematic Review of Research and Applications. Educational Technology, 17(4), 133-149. https://www.jstor.org/stable/jeductechsoci.1 7.4.133

Bicen, H., \& Bal, E. (2016). Determination of Student Opinions in Augmented Reality. World Journal on Educational Technology, 8(3), 205-209. Retrieved from https://unpub.eu/ojs/index.php/wjet/article/view/642

Billinghurst, M. (2002). Augmented Reality in Education. New Horizons for learning. Retrieved from http://www.solomonalexis.com/downloads/a r_edu.pdf.

Bondarenko, O.V., Pakhomova, O.V., \& Lewoniewski, W. (2020). The didactic potential of virtual information educational environment as a tool of geography students training. CEUR-WS, Vol 2547. Retrieved from 2547/paper01.pdf

Bower, M., Howe, C., McCredie, N., Robinson, A., \& Grover, D. (2014). Augmented Reality in education - cases, places and potentials. Educational Media International, 51(1), 1-15. doi: 10.1080/09523987.2014.889400

Cieutat, J.-M., Hugues, O. \& Ghouaiel, N. (2012). Active Learning based on the use of Augmented Reality Outline of Possible Applications: Serious Games, Scientific Experiments, Confronting Stud- ies with Creation, Training for Carrying out Technical Skills. International Journal of Computer Applications, Foundation of Computer
Science, 46(20), 31-36. Retrieved from https://hal.archives-ouvertes.fr/hal00739730/document

Dunleavy, M., Dede, C., \& Mitchell, R. (2009). Affordances and limitations of immersive participatory augmented reality simulations for teaching and learning. Journal of Science Education and Technology, 18(1), 7-22. https://doi.org/10.1007/s10956-0089119-1

Fernandez, M. (2017). Augmented Virtual Reality: How to Improve Education Systems. High. Learn. Res. Commun, 7 (1). DOI: 10.18870/hlrc.v7i1.373

Firmansyah, R., Putri, D. M., Wicaksono, M. G. S., Putri, S. F., Widianto, A. A., \& Palil, M. R. (2021). Educational Transformation: An Evaluation of Online Learning Due to COVID-19. International Journal of Emerging Technologies in Learning, 16(7), 61-76. https://doi.org/10.3991/ijet.v16i07.21201

Han, J., Jo, M., Hyun, E., \& So, H. (2015). Examining young children's perception toward augmented reality-infused dramatic play. Educational Technology Research and Development, 63(3), 455-474. https://doi.org/10.1007/s11423015-9374-9

Hidayat, H., Sukmawarti, S., \& Suwanto, S. (2021). The application of augmented reality in elementary school education. Research, Society and Development, [S. 1.], 10(3), p. e14910312823,. DOI: $10.33448 /$ rsdv10i3.12823.

Hruntova, T.V., Yechkalo, Yu.V., Striuk, A.M., \& Pikilnyak, A.V. (2018). Augmented Reality Tools in Physics Training at Higher Technical Educational Institutions. CEUR Workshop Proceedings, vol 2257, 33-40. Retrieved from http://ceur-ws.org/Vol2257/paper04.pdf

Ivanov, V., Pavlenko, I., Trojanowska, J., Zuban, Y., Samokhvalov, D., \& Bun, P. (2018). Using the augmented reality for training engineering students. In: Bruzzone, A.G., Ginters, E., Mendivil, E.G. et al. (eds.) Proceedings of the International Conference of the Virtual and Augmented Reality in Education, VARE 2018, Budapest, Hungary, 57-64. http://www.mscles.org/proceedings/vare/2018/VARE2018.p df

Pashnev, B. (2007). Psychodiagnostics of giftedness. Kharkiv: Osnova. (In ukranian)

Prikhodko, Yu. \& Yurchenko, V. (2020). Psychological dictionary-reference. Karavela. Retrieved from https://ispp.org.ua/wp- 


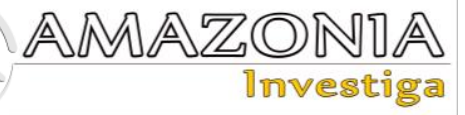

content/uploads/2021/02/Prykhodko_Yurche nko_2020_PSYKHOL-SLOVNYKDOVIDNYK_tytul_zmist.pdf.

Putra, A. K., Sumarmi, S., Sahrina, A., Fajrilia, A., Islam, M. N., \& Yembuu, B. (2021). Effect of Mobile-Augmented Reality (MAR) in Digital Encyclopedia on The Complex Problem Solving and Attitudes of Undergraduate Student. International Journal of Emerging Technologies in Learning, 16(7), 119-134. https://doi.org/10.3991/ijet.v16i07.21223

Repkina, G.V.\& Zaika, E.V. (1993). Assessment of the level of formation of educational activity: $b$ assistance to the primary school teacher. Tomsk: Peleng. (In Russian)

Rizov, T., \& Rizova, E. (2015). Augmented reality as a teaching tool in higher education. International Journal of Cognitive Research in Science, Engineering and Education (IJCRSEE), 3(1), 7-15. https://doi.org/10.23947/2334-8496-2015-31-7-15
Sagan, O. \& Lazaruk, V. (2020). Transformations of educational technologies based on the principles of digital didactics. Pedagogical Sciences, 92, 91-95. https://doi.org/10.32999/ksu24131865/2020-92-95/

Sagan, O., Yakovleva, S., Anisimova, E., Balokha, A. \& Yeremenko, H. (2020). Digital didactics as a new model in the theory of education. Revista Inclusiones, Vol. 7 num Especial, 193-204. Retrieved from http://bkp.revistainclusiones.org/gallery/17\% 20vol\%207\%20num\%20especialleabriljunio 2020revinclusi.pdf

Terletska, L. (2013). Age psychology and psychodiagnostics: a textbook. Kyiv: VDSlovo. (in Ukranian)

Tran, K., Nguyen, P., Do, H \& Nguyen, L. (2020). University students' insight on brand equity. Management Science Letters, 10(9), 2053-2062.

https://doi.org/10.5267/j.msl.2020.2.006 